\title{
Cell Mergers and their Impact on Cloud-to-Ground Lightning over the Houston Area
}

\author{
Michael L. Gauthier \\ United States Air Force Academy \\ Department of Physics \\ 2304 Fairchild Hall, Suite 2A45 \\ USAF Academy, Colorado 80840 \\ Walter A. Petersen \\ NASA Marshall Space Flight Center \\ NSSTC/Earth Sciences Office VP-61 \\ 320 Sparkman Drive \\ Huntsville, Alabama 35805 \\ and \\ Lawrence D. Carey \\ Earth System Science Center \\ National Space Science and Technology Center \\ University of Alabama in Huntsville \\ 320 Sparkman Drive \\ Huntsville, Alabama 35805
}

DRAFT $1 / 30 / 2009$

Corresponding author address: Lt Col Michael L. Gauthier, Department of Physics, 2304 Fairchild Hall, Suite 2A45, United States Air Force Academy, USAFA, CO 80840

E-mail: Michael.Gauthier@USAFA.edu

Voice: (719)333-2370

Fax: (719)333-3182 


\begin{abstract}
A previous hypothesis advanced from observational studies such as METROMEX suggests that the intensity, frequency, and organization of cumulus convection may be impacted by the forcing of enhanced merger activity downstream of urban zones. A resulting corollary is that cities may exert an indirect anthropogenic "forcing" of parameters related to convection and associated phenomena such as lightning and precipitation. This paper investigates the urban merger hypothesis by examining the role of convective cell mergers on the existence and persistence of the Houston lightning "anomaly", a local maximum in cloud-to-ground (CG) lightning activity documented to exist over and east of Houston.

Using eight summer seasons of peak columnar radar reflectivity, CG lightning data and a cell-tracking algorithm, a two-dimensional cell merger climatology is created for portions of eastern Texas and Louisiana. Results from the tracking and analysis of over 3.8 million cells indicate that merger-driven enhancements in convection induce a positive response $(\mathrm{O} 46 \%)$ in ground-flash densities throughout the domain, with areas of enhanced lightning typically being co-located with areas of enhanced merger activity. However, while mergers over the Houston area (relative to elsewhere in the domain) do result in more vigorous convective cells that produce larger CG flash densities, we find that CG lightning contributions due to mergers are distributed similarly throughout the domain. Hence while we demonstrate that cell mergers do greatly impact the production of lightning, the urban cell merger hypothesis does not uniquely explain the presence of a local lightning maximum near and downstream of Houston.
\end{abstract}

KEY WORDS: Lightning, Radar, Cell Merger 


\section{Introduction}

Anthropogenic influences such as the urban heat island [UHI; see Arnfield (2003) for extensive discussion] and increased aerosol concentrations have been postulated for many years to have an effect on lower tropospheric chemistry, convection, lightning and rainfall (e.g., Huff and Changnon, 1973; Westcott, 1995; Jauregui and Romales, 1996; Rosenfeld and Lensky, 1998; Bornstein and Lin, 2000; Shepherd et al., 2002; Rosenfeld and Woodley, 2003). Moreover, these influences have been invoked as possible explanations for cloud-to-ground (CG) lightning anomalies observed over metropolitan areas such as Houston, Texas. In particular, Orville et al. (2001) and Steiger et al. (2002) reported a 45\% increase in annual CG lightning flash densities over and downwind of the Houston urban corridor relative to rural surroundings citing anthropogenic influences as possible causative mechanisms.

One alternate hypothesis advanced as result of radar studies of convection during METROMEX (Metropolitan Meteorological Experiment; Changnon et al., 1971) that has been relatively unexplored as it pertains to the Houston lightning "anomaly" concerns the influence of the urban environment on convective frequency and upscale (i.e., mesoscale) organization. The suggestion here is that cities may exert an indirect anthropogenic "forcing" of parameters that are either directly or indirectly related to cumulus convection and associated phenomena such as lightning and precipitation. Specifically, results from this early-1970s campaign suggest that convective intensity may be impacted by urban forcing of enhanced merger activity downstream of urban corridors (Changnon et al., 1976). Through the development of coincident climatologies of radar derived cell merger occurrence and CG lightning, this paper investigates the urban-merger hypothesis by examining the spatial distribution and role of convective cell mergers on the existence and persistence of the Houston lightning "anomaly". 
Theoretically, it is conceivable to extend the METROMEX observations of enhanced storm mergers downwind of the St. Louis urban area as a plausible explanation for the enhanced lightning ground flash densities that were found in the same location, as noted by Westcott (1995). In general, merged systems yield more than an order of magnitude more precipitation than their unmerged counterparts (Simpson and Woodley, 1971; Simpson et al., 1980), and are also more vertically developed and intense than those that are not (Houze and Cheng, 1977; Westcott, 1984). From a thunderstorm electrification stand-point, one would also expect the merger-induced enhancements in convective vigor to be accompanied by enhanced concentrations precipitation sized ice, collocated with super-cooled liquid water leading to enhanced thunderstorm electrification and lightning (c.f., Carey and Rutledge, 2000; Petersen et al., 2005; Gauthier et al., 2006).

Observationally, the impact of cell mergers on upscale growth and lightning production was presented for deep island convection occurring just off tropical northern Australia (i.e., Tiwi island thunderstorms) by Carey and Rutledge (2000), who noted that once cold-pool outflow boundaries over the Tiwi Islands associated with precipitating convective cells began to interact with the sea breeze front, the previously isolated cells began to merge, resulting in vigorous upscale growth, accompanied by significant production of mixed phase ice mass, significant electric fields, and lightning.

Relative to the Houston metropolis, the UHI along with other mesoscale boundaries (e.g., the sea breeze) provide mechanisms to trigger and release instability in the air passing overhead. The UHI and sea breeze induced convergence boundaries can then interact favorably with cold pool boundaries generated by the downdrafts of dissipating convection to trigger new convective cells, which can then merge with older cells, resulting in upscale development. With regards to 
the multitude of hypotheses offered to explain the presence of the Houston lightning anomaly, the words of the medieval English philosopher and Franciscan monk William of Ockham [ca. 1285-1349], "Pluralitas non est ponenda sine neccesitate" or "plurality should not be posited without necessity", may prove to be quite applicable. Specifically, when faced with several possibilities what is the simplest or most obvious explanation for the facts? Given the complexities of the problem at hand, it seems equally plausible that a "first order" explanation involves some combination of UHI convergence and thermodynamics, perhaps interacting with the sea breeze front, resulting in enhanced and/or more frequent convective initiation, and likely merging, of convective cells over and downwind of Houston.

\section{Data and method}

The analyses conducted in this study rely on a fused dataset spanning eight summer seasons (JJA, 1996 - 2003) to develop a regional, two-dimensional (2D) cell merger climatology for portions of eastern Texas and Louisiana (see Figure 1). Having a horizontal resolution of 2 $\mathrm{km} \times 2 \mathrm{~km}$, the $2 \mathrm{D}$ composite radar reflectivity data derived from the National Weather Service (NWS) Weather Surveillance Radar-1988 Doppler (WSR-88D) network is digitized every 15 minutes with peak columnar reflectivity values available for each grid point. Used as a primary input into a cell tracking algorithm (described below), composite reflectivity data (comprised of 16 levels of reflectivity beginning at level- $0[0-5 \mathrm{dBZ}]$ with increments every $5 \mathrm{dBz}$ ) was coupled with corresponding CG lightning data. Here, ground strikes detected by the National Lightning Detection Network (NLDN; Cummins et al., 1998) were gridded to match the horizontal dimensions of the Cartesian composite reflectivity grid for each of $80000+$ time steps (15-minute temporal resolution). Consistent with previous lightning studies over the same 
domain (i.e., Gauthier et al., 2005; Gauthier et al., 2006), we have chosen to disregard flashes with positive peak currents less than $10 \mathrm{kA}$ following the recommendations of Cummins et al. (1998) and Wacker and Orville (1999a,b). The fused composite reflectivity and CG lightning datasets were used as input parameters to a variant of the Thunderstorm Identification, Tracking, Analysis and Nowcasting (TITAN) software (Dixon and Wiener, 1993) where individual cells were identified and tracked throughout the domain over the entire period of record (POR; JJA, $1996-2003)$.

Before further discussion of the methodology employed within the cell-tracking algorithm, it is prudent to first define the fundamental building block of a merger - the convective cell (or "composite cell" in this case). For the purposes of this climatological study, a convective cell was defined as a contiguous region of composite reflectivity with values greater than or equal to $30-34 \mathrm{dBZ}\left(\mathrm{Z}_{\text {thresh }}=\right.$ level-6) with minimum and maximum areas of $8 \mathrm{~km}^{2}(2$ pixels) and $5,988 \mathrm{~km}^{2}(1,497$ pixels), respectively. Although somewhat arbitrary, these spatial constraints were determined via experimental and statistical means. To investigate the sensitivity of the cell-tracking algorithm to the composite reflectivity threshold $\left(Z_{\text {thresh }}\right)$ was set to levels-5, 6, and 7 (25-29, 30-34 and 35-39 dBZ, respectively). For all three cases the identification and tracking technique worked well. The level-7 storms were smaller and more intense (on average) than the level-5 and level-6 storm echo areas; the lower the threshold, the greater the number of apparent mergers. Conversely, increasing $Z_{\text {thresh }}$ resulted in a greater number of tracked cells. Based on the results of sensitivity testing, $Z_{\text {thresh }}$ was set to level-6 (30$35 \mathrm{dBZ}$ ) for the final development of the cell-merger climatology, a reasonable threshold for the partitioning of convective activity (Dixon and Wiener, 1993; Demott and Rutledge, 1998). The use of spatial thresholds was necessary to eliminate ground clutter at the individual radar 
locations (lower threshold) as well as to minimize the impact of geo-location errors (discussed below) associated with larger tracked composite cells (upper threshold). Specifically, an examination of the merged cell area statistics revealed a positively skewed, non-Gaussian distribution with an upper-outer fence (defined as $\mathrm{Q}_{3}+3 \mathrm{IQR}$, where IQR is the inter-quartile range and Q3 represents the $75^{\text {th }}$ percentile of the cumulative distribution function [CDF] associated with cell areas) of $5988 \mathrm{~km}^{2}$. As the upper-outer fence of the data distribution typically represents the upper threshold of the usable dataset, with values in excess deemed extreme outliers (Wilkes, 1995), the maximum area threshold was set to equal this value.

Using geometric logic regarding "composite cell" positions and shapes, the cell-tracking algorithm first identified cells that occurred within the domain. The algorithm then tracked identified cells, and determined if and when mergers occurred. Tracking was accomplished by matching cells at some time $\left(t_{1}\right)$ with their corresponding counterparts in a subsequent time frame $\left(t_{2}\right)$. Done successively, the cells were able to be tracked for their entire duration. Mergers were identified to have occurred when the region between two or more separated cells at $t_{1}$ exceeded $Z_{\text {thresh }}$ at $t_{2}$ (i.e., the best-fit ellipses overlapped), at which point a new best-fit ellipse was created with the cell properties described in Table 1 being geo-located with the centroid of the new merger ellipse. This means that, in the case of flash counts, all flashes associated with the pixels comprising the merged cell (i.e., flashes occurring \pm 7.5 minutes of the valid time that were located within a pixel whose value is $\geq Z_{\text {thresh }}$ ) were geo-located with the merger centroid, hence losing their spatial identity, relative to this location.

Spatial distributions of cell properties described in Table 1 (both individual and only those identified as merged cells) were then generated and examined in an effort to determine the statistical differences between the location, timing, and properties of merged and individual cells. 


\section{Results and discussion}

Application of the cell-tracking algorithm to the $80000+$ time-steps contained within the fused composite reflectivity - lightning dataset resulted in the tracking and analysis of 3.8 million individual cells, 627569 of which were classified as parents to 190477 merged cells (summary statistics are presented in Table 2). We begin our discussion with an examination of the spatial distributions of cell and cell merger occurrences throughout the domain. Spatially, there appears to be excellent agreement between the results of the independent analysis of CG lightning data performed by Gauthier et al. (2005), and the geo-location of cell and cell merger centroids (compare Figure 1 and Figures $2 \mathrm{a}$ and $2 \mathrm{~b}$ ). That is to say that convective cells tend to occur more frequently along the coast, with increasing frequency from west to east (Figure 2a). Regarding cell mergers, there appears to be a preferred location of cell merger occurrence coinciding with the climatological enhancements in CG lightning activity throughout the domain (compare Figures $2 \mathrm{~b}$ and $1 \mathrm{a}$ ). Additionally, enhanced flash counts gathered through the tracking of all 3.8 million cells appear to be consistent with the flash density patterns identified by Gauthier et al. (2005). Here, flash counts associated with each cell occurring within a given pixel were used to construct the spatial distribution of "tracker produced" mean summer flash densities (Figure 3a), scaled to match the independent lightning analysis conducted by Gauthier et al. (Figure 1a). Given the slight mismatch in PORs between the lightning climatology presented by Gauthier et al. $(2005 ; 1995$ - 2003) and the analysis conducted herein $(1996$ 2003, with intermittent gaps) and the limitations inherent within the cell-tracking algorithm and its associated geo-location assumptions (recall that all CGs coming to ground within the confines of $Z_{\text {thresh }}$ were geo-located with the cell centroid and associated with a single pixel), the 
qualitative agreement between the observed (Figure 1a) and the tracker produced (Figure 3a) lightning climatologies is remarkable, providing a strong indicator that the cell tracking algorithm is functioning as designed. Given the fidelity of the tracker-produced climatology, we then created a flash density "anomaly" map (Figure 3b), as in Gauthier et al., (see Figure 1b), by normalizing the mean flash density of each pixel $(\hat{x})$ by the mean flash density of the entire domain $(\bar{x}$; i.e., $\hat{x} / \bar{x})$; values $>1(<1)$ are referred to as "positive" ("negative") anomalies. Consistent with previous studies (c.f., Simpson and Woodley, 1971; Houze and Cheng, 1977; Simpson et al., 1980; Westcott, 1984; Carey and Rutledge, 2000), the data summarized in Table 2 confirms that merged cells are indeed larger and more intense than their unmerged counterparts. Throughout the entire domain (see first row in Table 2) we find the average merger to be on the order of 8 times larger (horizontal extent) than the average parent cell, producing upwards of 11 times as much lightning with mean flash densities nearly an order of magnitude greater than the mean parent cell. Further, findings indicate that CG lightning associated with merged cells contributes roughly $46 \%$ of the total CG lightning occurring throughout the domain (Table 3).

To determine how parent and merged cell characteristics varied from location to location throughout the domain, nine separate analysis boxes (each $4080 \mathrm{~km}^{2}$ in size) were qualitatively selected based upon visual inspection of the spatial distribution of merger occurrences (Figure 2b). Throughout the entire POR, there were a total of 1567 mergers whose centroids were geolocated over the Houston area (IAH box in Figure $2 b$ ). With the exception of analysis boxes $G$ and $\mathrm{H}$, the remaining boxes were chosen such that a similar number $( \pm 30 \%$ of IAH merger count) of mergers occurred within each. Boxes G (located in the vicinity of Dallas, TX) and H (located within Gulf of Mexico) were chosen for comparative purposes as the Dallas area is 
another major urban area within the domain that exits in a different meteorological regime, while the box located over the open Gulf waters (box $\mathrm{H}$ ) contains a relative enhancement in merger activity (relative to other open water portions within the domain). Application of a nonparametric one-sided Wilcoxon Rank-Sum test for statistical significance reveals that relative to the Houston area (IAH box), cell mergers elsewhere in Texas (i.e., analysis boxes A, B, C, D, and $\mathrm{G}$ ) have statistically larger areas (on the order of $10 \%$; at $\mathrm{p}$-values $<0.05$ ), while those in analysis boxes $\mathrm{E}, \mathrm{F}$ and $\mathrm{H}$ were found to be statistically similar (summarized in Table 2). Additionally, with the exception of analysis boxes B (located to the northeast of Houston) and F (located along the central Louisiana Coast), cell mergers elsewhere produce, on average, $50 \%$ less lightning than mergers occurring over the Houston area. When comparing the mean flash densities of mergers occurring over the Houston area to those occurring elsewhere within the domain, we find the mean Houston cell merger to have flash densities nearly double the mean flash density per merger elsewhere, all statistically significant $(p<0.05$; see last column in Table 2).

As previously mentioned, the degree of similarity between the observed and trackerproduced CG lightning climatologies provides a considerable degree of confidence in the performance of the cell-tracking algorithm. The total number of ground flashes contained within a given pixel (i.e., total flash count, $\mathrm{FC}_{\mathrm{tot}}$ ) throughout the domain is equal to the sum of ground flashes associated with isolated convective cells $\left(\mathrm{FC}_{\mathrm{i}}\right)$, parent cells $\left(\mathrm{FC}_{\mathrm{p}}\right)$ and merged cells $\left(\mathrm{FC}_{\mathrm{m}}\right)$ such that $\mathrm{FC}_{\mathrm{tot}}=\mathrm{FC}_{\mathrm{i}}+\mathrm{FC}_{\mathrm{p}}+\mathrm{FC}_{\mathrm{m}}$. Since the lightning contribution due to mergers at each pixel is known, it can be subtracted from $\mathrm{FC}_{\text {tot }}$ to determine if the flash density anomaly persists absent the influence of mergers. Figure 3c presents the spatial distribution of tracker-produced mean summer flash densities devoid of ground flashes associated with cells classified as mergers. 
Note the significant decrease in mean flash densities throughout the domain (on the order of 46\%, domain-wide; Table 3). Despite the significant impact on the magnitude of flash densities, relative enhancements in flash densities remain apparent throughout the domain, particularly over the Houston area. To further investigate the impact of the exclusion of ground strikes associated with cell mergers on the lightning anomaly, a flash density anomaly map (similar to Figure 3b) was created for the "merger removed" lightning climatology, the result of which (Figure 3d) yields a very interesting result. Despite the significant decrease in the magnitude of pixel mean flash densities associated with the removal of the lightning strikes attributed to mergers, we find little change in the spatial distribution of flash density anomalies (compare Figure $3 \mathrm{~b}$ [with mergers] to Figure $3 \mathrm{~d}$ [mergers removed]), thus indicating that mergers contribute roughly the same percentage of the total lightning "signal", regardless of geographic location (see second column in Table 3). In fact, the mean flash density anomaly over the Houston area (i.e., the IAH box) actually increased from 2.64 to 2.84 times the domain mean when merger related ground strikes were excluded (Table 3). These findings have significant implications pertaining to the applicability of the cell-merger hypothesis under investigation; clearly cell-mergers are not the predominant causative mechanism behind the Houston CG lightning anomaly.

\section{Conclusions}

Using eight summer seasons (JJA, 1996 - 2003) of peak columnar radar reflectivity and associated CG lightning data coupled with cell tracking software, a two-dimensional cell merger climatology was created for portions of eastern Texas and Louisiana. Through the tracking and analysis of over 3.8 million "composite" cells, the impact of convective cell mergers on the 
Houston CG lightning anomaly was investigated. Results quantify the general importance of cell-mergers on the upscale growth of convection. Not unexpectedly, we find that merger-driven enhancements in convection induce a positive response (O 46\%) in ground flash densities throughout the domain, with areas of enhanced ground flash densities typically being co-located with areas of enhanced merger activity. However, while mergers over the Houston area (relative to elsewhere in the domain) do result in more vigorous convective cells that produce more lightning with larger flash densities, findings suggest that $\mathrm{CG}$ lightning contributions due to mergers are distributed similarly throughout the domain. Hence while we have demonstrated that cell mergers do greatly impact the production of lightning, the urban cell merger hypothesis does not explain, exclusively, the presence of a local lightning anomaly near and downstream of Houston (or elsewhere in the domain). 


\section{Acknowledgments.}

This research was supported by funding from the U.S. Air Force Academy through the Air Force Institute of Technology (MLG), NASA's Earth Sciences Program (WAP), and NSF grant ATM0442011 (LDC). The views expressed in this paper are those of the authors and do not reflect the official policy or position of the U.S. Air Force, Department of Defense, or the U.S.

Government. 
(a)

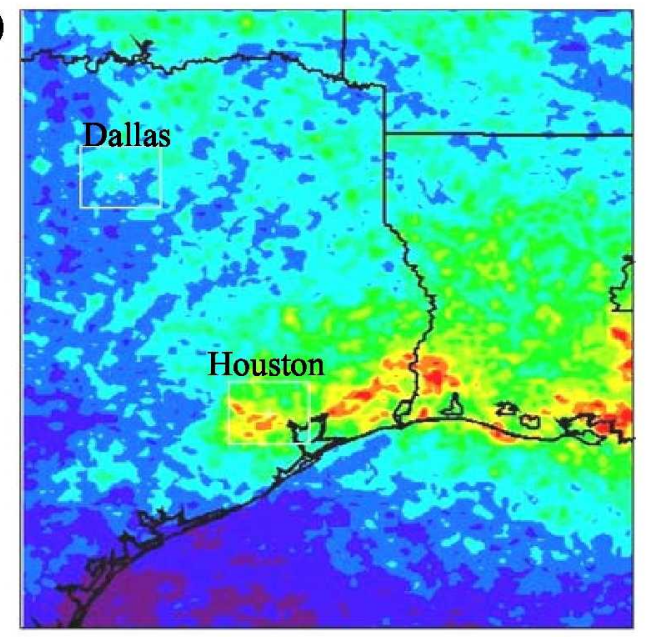

(b)

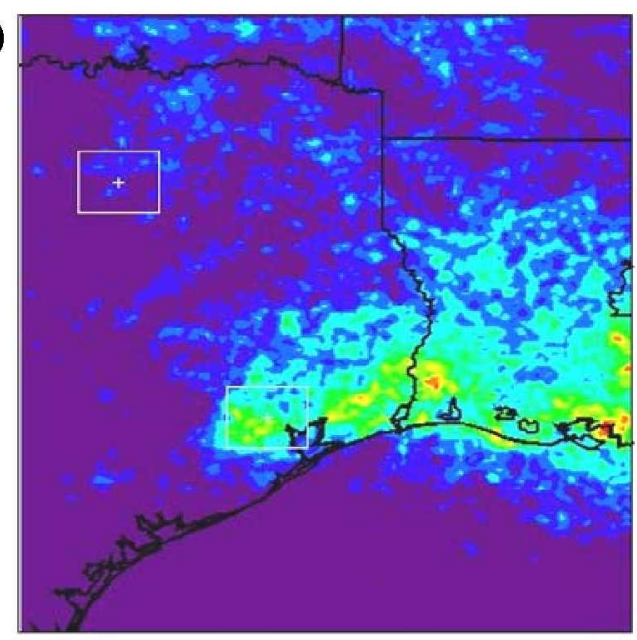

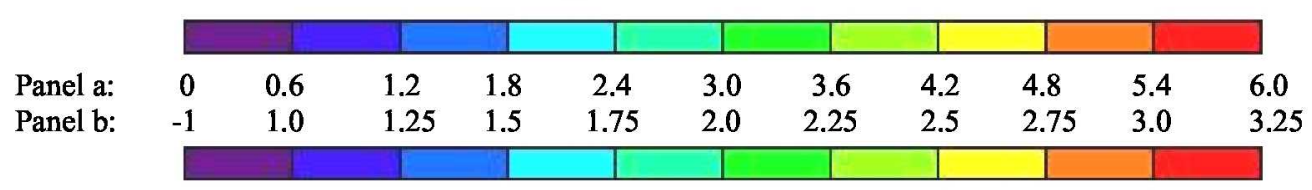

Figure 1 Nine-year (1995-2003) summer season spatial distribution of (a) mean ground flash density [flashes $\mathrm{km}^{-2}$ summer ${ }^{-1}$ ] and (b) flash density anomalies (created by the normalization of the mean flash density of each pixel by the domain mean), values $>1(<1)$ indicate positive (negative) anomalies [dimensionless]; appropriate scales for the color bar associated with each panel are as indicated. Urban areas associated with the Houston and Dallas metropolitan areas are approximated by $0.75^{\circ}$ latitude $\times 0.85^{\circ}$ longitude boxes centered on each city. Adapted from Figures $1 \mathrm{~b}$ and 2a of Gauthier et al. [2005]. 
(a)

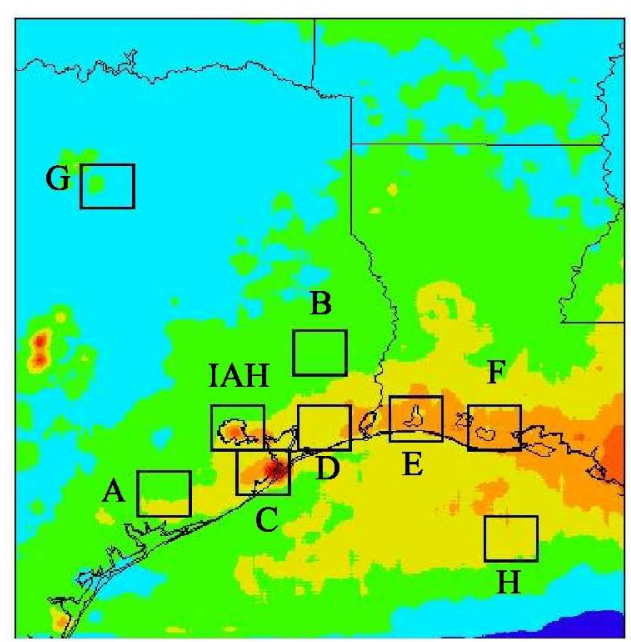

(b)

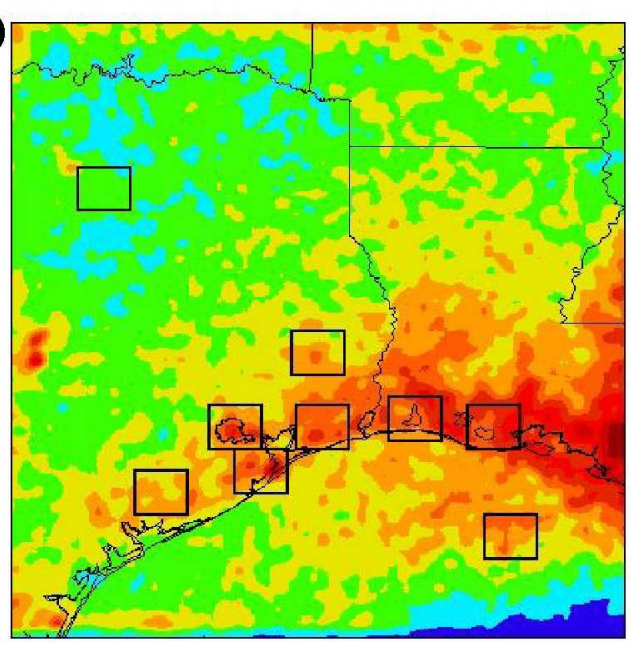

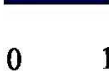

$10 \quad 20 \quad 30$

40

50

$60 \quad 70$

$80 \quad 90 \quad 100$

Figure 2 Eight-year (1996 - 2003) summer season spatial distribution of (a) relative frequency of occurrence [\%] of $3.8 \times 10^{6}$ composite cell centroid locations, (b) spatial variations of the relative frequency of occurrence [\%] of $3.9 \times 10^{5}$ composite cell merger centroids. Black boxes represent sub-domains referenced in text. 
(a)

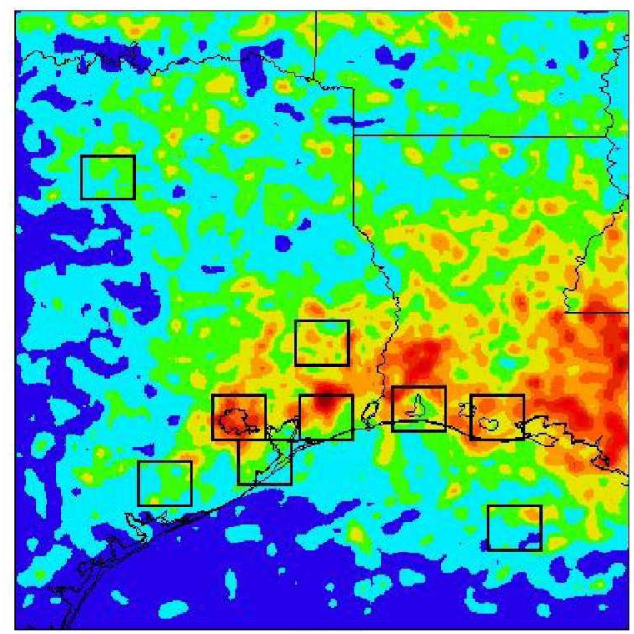

(c)

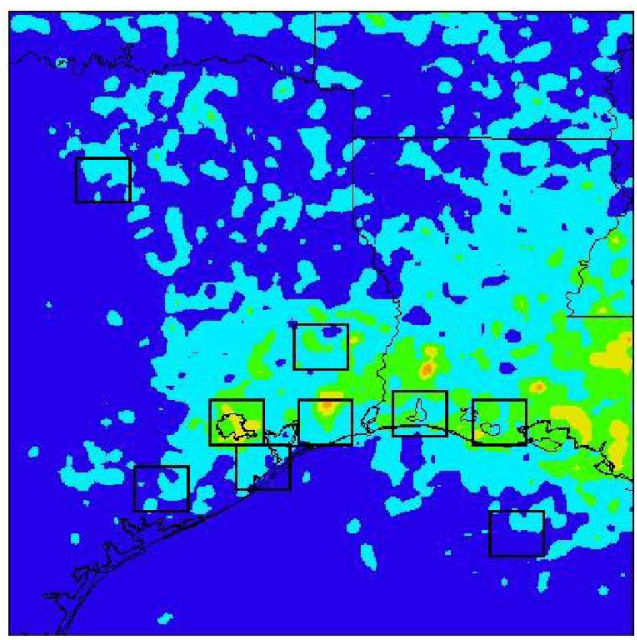

(b)

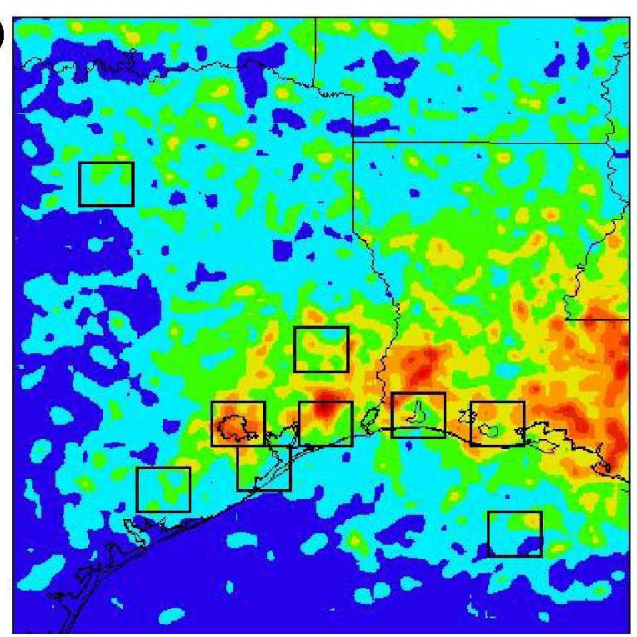

(d)

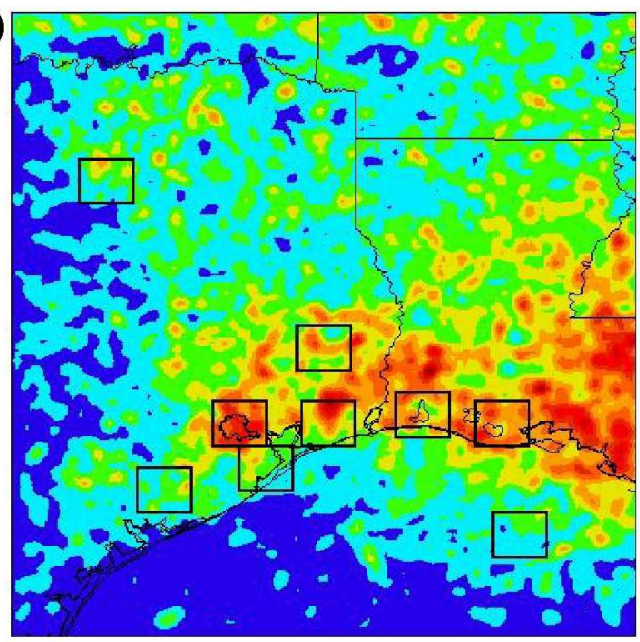

Panel (a \& c): 0

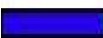

Panel (b \& d): 0

$\begin{array}{lll}0.6 & 1.2 & 1.8 \\ 0.5 & 1.0 & 1.5\end{array}$

(1.

Figure 3 Eight-year (1996 - 2003) summer season spatial distribution of (a) "Tracker produced" CG lightning climatology depicting the distribution of CG flashes associated with all cells in panel [flashes $\mathrm{km}^{-2}$ summer ${ }^{-1}$ ], (b) spatial distribution of flash density anomalies [dimensionless] created by normalization of mean flash densities of each pixel in panel (a) by the domain mean of panel (b), (c) ground flash densities and (d) anomalies (as presented in panels a and b, respectively) excluding ground flashes associated with cells classified as mergers. Appropriate scales for the color bar associated with each panel are as indicated. Black boxes represent sub-domains referenced in text. 
Table 1 Computed properties for each identified "composite cell":

- Mean composite reflectivity enclosed within the $Z_{\text {thresh }}$ contour

- Area enclosed within the $Z_{\text {thresh }}$ contour

- The size and shape of the storm projected onto a horizontal plane approximated by a best fit ellipse [ellipse properties included: latitude and longitude of centroid, major and minor axes, and orientation of major axis. Note that all cell properties were geo-located with the cell centroid (further detailed below)]

- Flash Count (FC) - as the time interval between images was 15 minutes (unless data was missing), cell total flash counts were taken as the sum of flashes occurring \pm 7.5 minutes of the composite reflectivity valid time, geo-located with pixels whose values were $\geq$ $Z_{\text {thresh. }}$ Note, this constraint eliminated flashes that may have been associated with the cell of interest, but did not come to ground within the confines of the $Z_{\text {thresh }}$ contour; at the same time this methodology may have included ground strikes that originated in one cell and terminated within the cell of interest

- Flash Density (FD) - together, cell FC and area were used to compute the FD for each cell (flashes $\mathrm{km}^{-2}$ hour ${ }^{-1}$ ) 
Table 2 Composite cell summary statistics for all, parent and merged cells generated from the tracking and analysis of $3.8 \times 10^{6}$ cells over 8 -summer seasons. Bold un-shaded values are statistically different than the corresponding IAH value for each cell type (at p-values < 0.05 ); statistical significance based on a nonparametric one-sided Wilcoxon Rank-Sum test.

\begin{tabular}{|c|c|c|c|c|c|c|c|c|c|}
\hline \multirow[b]{2}{*}{$\begin{array}{c}\text { Analysis } \\
\text { Box }\end{array}$} & \multirow{2}{*}{$\begin{array}{l}\text { ALL CELLS } \\
\text { Count }\end{array}$} & \multicolumn{4}{|c|}{ PARENT CELLS } & \multicolumn{4}{|c|}{ MERGED CELLS } \\
\hline & & Count & $\begin{array}{c}\text { Mean } \\
\text { Flash } \\
\text { Count per }\end{array}$ & $\begin{array}{c}\text { Mean } \\
\text { Area } \\
{\left[\mathrm{km}^{2}\right]}\end{array}$ & $\begin{array}{c}\text { Mean Flash } \\
\text { Density per } \\
{\left[\text { flashes } \mathrm{km}^{-2} \text { ] }\right.}\end{array}$ & Count & $\begin{array}{c}\text { Mean } \\
\text { Flash } \\
\text { Count per }\end{array}$ & $\begin{array}{c}\text { Mean } \\
\text { Area } \\
{\left[\mathrm{km}^{2}\right]}\end{array}$ & $\begin{array}{c}\text { Mean Flash } \\
\text { Density per } \\
{\left[\text { flashes } \mathrm{km}^{-2} \text { ] }\right.}\end{array}$ \\
\hline$\overline{\text { DOMAIN }}$ & $3,808,068$ & 627,569 & 1.11 & 107 & 0.0014 & 190,477 & 12.5 & 798 & 0.0100 \\
\hline IAH & 28,919 & 4,189 & 2.49 & 89 & 0.0048 & 1,567 & 21.47 & 663 & 0.0220 \\
\hline $\mathrm{A}$ & 25,225 & 2,881 & 0.25 & 72 & 0.0003 & 1,316 & 10.13 & 792 & 0.0070 \\
\hline B & 23,571 & 3,817 & 0.89 & 108 & 0.0018 & 1,319 & 15.74 & 840 & 0.0130 \\
\hline $\mathrm{C}$ & 39,180 & 5,188 & 0.89 & 58 & 0.0013 & 1,638 & 10.46 & 529 & 0.0110 \\
\hline $\mathrm{D}$ & 31,442 & 5,212 & 0.62 & 105 & 0.0016 & 1,715 & 17.57 & 742 & 0.0140 \\
\hline $\mathrm{E}$ & 36,426 & 5,303 & 0.88 & 96 & 0.0012 & 1,750 & 12.2 & 698 & 0.0120 \\
\hline $\mathrm{F}$ & 38,161 & 6,564 & 2.76 & 168 & 0.0024 & 2,016 & 12.35 & 653 & 0.0140 \\
\hline $\mathrm{G}$ & 15,282 & 2,262 & 0.03 & 44 & 0.0005 & 777 & 17 & 840 & 0.0140 \\
\hline $\mathrm{H}$ & 12,447 & 1,927 & 1.18 & 86 & 0.0024 & 572 & 12.35 & 672 & 0.0110 \\
\hline
\end{tabular}


Table 3 The effect of excluding CG lightning associated with cells identified as merged cells.

\begin{tabular}{ccccc}
\hline & $\begin{array}{c}\text { Lightning } \\
\text { Contribution } \\
\text { due to }\end{array}$ & $\begin{array}{c}\text { Mean Flash } \\
\text { Analysis } \\
\text { Box }\end{array}$ & \begin{tabular}{c} 
Mensity \\
Mergers [\%] \\
Anomaly \\
\cline { 5 - 6 } $\begin{array}{c}\text { Density } \\
\text { Anomaly, } \\
\text { Mergers } \\
\text { Removed }\end{array}$
\end{tabular} & $\begin{array}{c}\text { Percent } \\
\text { Change [\%] }\end{array}$ \\
\cline { 1 - 4 } IAH & $46 \%$ & 1.00 & 1.00 & $0 \%$ \\
A & $42 \%$ & 2.64 & 2.84 & $8 \%$ \\
B & $45 \%$ & 1.08 & 1.09 & $1 \%$ \\
C & $43 \%$ & 1.73 & 1.81 & $5 \%$ \\
D & $47 \%$ & 1.24 & 1.22 & $-2 \%$ \\
E & $48 \%$ & 2.12 & 2.04 & $-4 \%$ \\
F & $40 \%$ & 1.90 & 2.00 & $5 \%$ \\
G & $40 \%$ & 2.19 & 2.42 & $11 \%$ \\
H & $42 \%$ & 1.00 & 0.90 & $-10 \%$ \\
& $53 \%$ & 1.08 & 1.15 & $6 \%$ \\
\hline
\end{tabular}




\section{References}

Arnfield, A. J., 2003. Two decades of urban climate research: A review of turbulence, exchanges of energy and water, and the urban heat island. Int. J. Climatol., 23, 1-26.

Bornstein, R., Lin, Q., 2000. Urban heat islands and summertime convective thunderstorms in Atlanta: Three case studies. Atmos. Environ., 34, 507-516.

Carey, L. D., Rutledge, S. A., 2000. The relationship between precipitation and lightning in tropical island convection: A C-band polarimetric radar study. Mon. Weather Rev. $128,2687-2710$.

Changnon, S. A., Jr., Huff, F. A., Semonin, R. G., 1971. METROMEX: An investigation of inadvertent weather modification. Bull. Amer. Meteor. Soc., 52, 958-968.

Changnon, S. A., Jr., Semonin, R. G., Huff, F. A., 1976. A hypothesis for urban rainfall anomalies. J. Appl. Meteorol., 15, 544-560.

Cummins, K. L., Murphy, M. J., Bardo, E. A., Hiscox, W. L., Pyle, R. B., Pifer, A. E., 1998. A combined TOA/MDF technology upgrade of the U.S. National Lightning Detection Network. J. Geophys. Res., 103(D8). doi: 10.1029/98JD00153.

DeMott, C. A., Rutledge, S. A., 1998. The vertical structure of TOGA COARE convection. Part I: Radar echo distributions. J. Atmos. Sci., 55, 2730-2747. 
Dixon, M., Wiener, G., 1993. TITAN: thunderstorm identification, tracking, analysis, and nowcasting —A radar-based methodology. J. Atmos. Ocn. Tech., 10, 785-797.

Gauthier, M. L., Petersen, W. A., Carey, L. D., Orville, R. E., 2005. Dissecting the anomaly: A closer look at the documented urban enhancement in summer season ground flash densities in and around the Houston area. Geophys. Res. Lett., 32, L10810. doi:10.1029/2005GL022725.

Gauthier, M. L., Petersen, W. A., Carey, L. D., Christian, H. J., 2006. Relationship between cloud-to-ground lightning and precipitation ice mass: A radar study over Houston. Geophys. Res. Lett., 33, L20803. doi:10.1029/2006GL027244.

Houze, R.A., Jr., Cheng, C., 1977. Radar characteristics of tropical convection observed during GATE: Mean properties and trends over the summer season. Mon. Wea. Rev., 105, 964-980.

Huff, F. A., Changnon, S. A., Jr, 1973. Precipitation modification by major urban areas. Bull. Amer. Meteor. Soc., 54, 1220-1232.

Jauregui, E., Romales, E., 1996. Urban effects on convective precipitation in Mexico City. Atmos. Environ., 30, 3383-3389. 
Orville, R. E., Huffines, G., Nielsen-Gammon, J., Zhang, R., Ely, B., Steiger, S., Phillips, S., Allen, S., Read, W., 2001. Enhancement of cloud-to-ground lightning over Houston, Texas. Geophys. Res. Lett., 28(13). doi:10.1029/2001GL012990.

Petersen, W. A., Christian, H. J., Rutledge, S. A., 2005. TRMM observations of the global relationship between ice water content and lightning. Geophys. Res. Lett., 32, L14819. doi:10.1029/2005GL023236.

Rosenfeld, D., Lensky, M. I., 1998. Space-borne based insights into precipitation formation processes in continental and maritime convective clouds. Bull. Am. Meteorol. Soc., 79, 2457-2476.

Rosenfeld, D., Woodley, W. L., 2003. Spaceborne inferences of cloud microstructure and precipitation processes: Synthesis, insights and implications, Cloud Systems, Hurricanes, and the Tropical Rainfall Measuring Mission (TRMM) - A tribute to Dr. Joanne Simpson, Eds. W-K Tao and R. Adler. Meteorological Monographs, 29, Amer. Meteor. Soc., 59-80.

Shepherd J. M., Pierce, H. F., Negri, A. J., 2002. Rainfall modification by major urban areas: Observations from spaceborne radar on the TRMM satellite. J. Appl. Meteor., 41, 689-701.

Simpson, J., Woodley, W. L., 1971. Seeding cumulus in Florida: New 1970 results. Science, 172, 117-126. 
Simpson, J., Westcott, N. E., Clerman, R. J., Pielke, R. A., 1980. On cumulus mergers. Arch. Met. Geoph. Biokl., 29, 1-40.

Steiger S. M., Orville, R. E., Huffines, G., 2002. Cloud-to-ground lightning characteristics over Houston, Texas: 1989-2000. J. Geophys. Res., 107(D11). doi:10.1029/2001JD001142.

Wacker, R. S., Orville, R. E., 1999a. Changes in measured lightning flash count and return stroke peak current after the 1994 U.S. National Lightning Detection Network upgrade: 1. Observations. J. Geophys. Res., 104(D2). doi:10.1029/1998JD200060.

Wacker, R. S., Orville, R. E., 1999b. Changes in measured lightning flash count and return stroke peak current after the 1994 U.S. National Lightning Detection Network upgrade: 2. Theory. J. Geophys. Res., 104(D2). doi:10.1029/1998JD200059.

Westcott, N. E., 1984. A historical perspective on cloud mergers. Bull. Amer. Meteor. Soc., 65, 219-226.

Westcott, N. E., 1995. Summer-time cloud-to-ground lightning activity around major Midwestern urban areas. J. App. Meteor., 34, 133-1642.

Wilkes, D. S., 1995. Statistical Methods in the Atmospheric Sciences. Academic Press, $465 \mathrm{pp}$. 